\title{
Pengembangan Model Kurikulum Sekolah Sepakbola (SSB) dengan Pemberian Konsep dan Media Audio Visual
}

\author{
Adi Sucipto \\ Program Studi Pendidikan Jasmani Kesehatan dan Rekreasi IKIP Budi Utomo Malang \\ Jalan Simpang Arjuno 14B Malang \\ Email: adis123.com@gmail.com \\ Budijanto \\ Program Studi Pendidikan Jasmani Kesehatan dan Rekreasi IKIP Budi Utomo Malang \\ Jalan Simpang Arjuno 14B Malang \\ Email: Budijanto.mkes@gmail.com
}

\begin{abstract}
Football School Curriculum development with giving of concept and audiovisual media aims to improve the quality of football skills. This type of research is the development of research.This study begins with a situation analysis, problem analysis, requirements analysis, design development, validation, limited testing and revision. From the analysis of the situation and the problems found problems being experienced by students Football School caused by factors both internal and external. Football school curriculum needs by providing concepts and audio-visual media, students of need to be given to the Football School. Giving concept before exercise is useful to strengthen memory skills related skills that will be implemented. Learning material that obtained through the medium of vision (visual media), can accelerate absorption learners in understanding literacy classes. The results of the needs analysis shows that Football School curriculum development by the giving concept and audiovisual media very necessary, to improve football skills.
\end{abstract}

Keyword: Development of curriculum, Football School, giving the concept, audio-visual media

Dewasa ini masyarakat Indonesia disuguhi dengan maraknya berdirinya sekolah-sekolah sepakbola (SSB) yang begitu banyak bagaikan jamur tumbuh di musim hujan. Klub-klub luar negeripun tidak mau ketinggalan seperti Soccer school Indonesia (SSI) yang dikelola Arsenal juga sudah buka di Indonesia. SSB Real Madrid, makin menyemarakkankeberadaan sekolah sepakbola (SSB) ) tentunya akan mempunyai dampak yang sangat baik bagi kemajuan sepakbola profesional. Dengan adanya SSB siswa yang mempunyai prestasi pada sepakbola akan dapat lebih terarah dan sistematis dalam pola latihan.Memang perkembangan sepakbola di Indonesia belum menggembirakan, jangankan di tingkat dunia di kawasan Asia Tenggara saja belum bisa berbicara banyak. Hal ini tentu harus diupayakan bagaimana pembinaan sepakbola yang baik yang bisa mendongkrak prestasi sepakbola kita. Melalui pengembangan kurikulum sekolah sepakbola merupakan sebuah upaya alternatif dalam meningkatkan prestasi sepakbola tersebut. Kita ketahui untuk menghasilkan prestasi tinggi pada pemain sepakbola memerlukan waktu latihan yang intensif yang terprogram melalui kurikulum. Berdasarkan hal tersebut perlu suatu kajian yang komprehensif terhadap semua aspek yang ada di sekolah-sekolah sepakbola (SSB).

Tujuan penelitian ini adalah: (1)Memperoleh data karakteristik model kurikulum di Sekolah Sepakbola (SSB). (2) Menemukan karakteris-tik model kurikulum dengan pemberian konsep dan media audio visual (KONAV) di Sekolah Sepakbola (SSB) Model evaluasi pembelajaran sepakbola di Sekolah Sepakbola (SSB) dengan Pemberian konsep dan media audio visual

Penyelidikan-penyelidikan psikologi telah dilaksanakan untuk menjelaskan bagaimana terjadinya belajar. Teori adalah gabungan antara kenyataan dan khayalan (fiksi) (Rahantoknam, 1988:3). Teori dimulai dengan kenyataan-kenyataan yang tampak pada waktu melakukan perumusan, tetapi sebaliknya teori harus mendukung, mengkonseptualisasikan, atau menghipotesiskan apa yangdiketahui. 
118 | Adi Sucipto \& Budijanto, Pengembangan Model Kurikulum Sekolah Sepakbola (SSB) ...

Penggunaan konsep sebelum melakukan sebuah tindakan yang disebut keterampilan atau skill mutlak diperlukan. Selama ini kadang manusia tidak menyadari kalau ia telah menggunakan teori dan konsep sebelum melakukan tindakan. Penggunaan konsep ini sebenarnya sudah masuk dalam fase-fase perkembangan keterampilan. Fase-fase perkembangan keterampilan anak dapat dijelaskan sebagai berikut:

\section{Fase-fase Perkembangan Keterampilan}

Fitts (1965) mencipatkan teori yang menyatakan belajar keterampilan dapat diselidiki dengan membagi proses belajar keterampilan menjadi tiga fase yaitu: 1) fase kognetif, 2) fase fiksasi, 3) fase otonom. Selanjutnya dalam mengajar keterampilan ada 4 bidang yang harus mendapat penekanan yaitu aspek kognetif, aspek persepsi, aspek koordinasi dan aspek pengendoran ketegangan (tention relaction).

Belajar keterampilan meliputi pembentukan suatu rencana motorik, maupun mengerah-kan perhatian untuk memilih stimuli membedakan isyarat-isyarat yang ada disekitarnya dan mengolah balikan (feedback) secara berkesinambungan. Adapun tahap-tahap belajar keterampilan tersebut meliputi: 1) formasi rencana, 2) sesion latihan, 3) fase pelaksanaan.

\section{Fase I: Tahap Formasi Rencana}

Pada fase ini disebut fase kognitif, siswa dan atlet harus memahami apa yang diperlukan oleh keterampilan atau "tugas tersebut" yaitu hakekat dan tujuan dari tugas tersebut. Siswa dan atlet harus memformulasikan rencana pelaksanaan (executive plan) dan ia telah memperoleh konsepkonsep verbal yang cukup, maka ia dapat mencernakan keterampilan tersebut sampai pada taraf tertentu. Lutan, (1988) mengemukakan bahwa proses penguasaan keterampilan dalam olahraga sama sekali tak lepas dari penguasaan informasi yang diterima seseorang sebelumnya. Pandangan ini beranggapan bahwa informasi yang datang diterima oleh seseorang, kemudian disimpan dalam berbagai sistem penyimpanan yang disebut memori. Dari memori inilah keterampilan diperagakan, termasuk keterampilan yang sangat sulit sekalipun.

Pemrosesan informasi dalam belajar motorik dapat dibagi menjadi tiga tahap: 1) tahap indentifikasi rangsang; 2) tahap seleksi respon; 3) tahap pemrograman respon (gambar 1.1.).

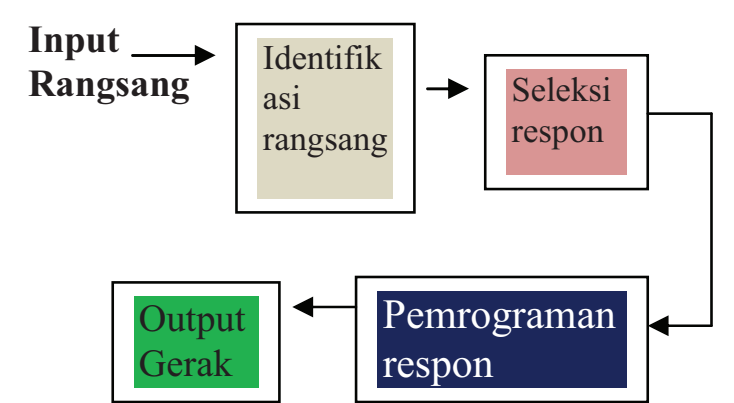

Gambar 1.1: Model Pemrosesan Informasi Motorik (Schmidt, 1982)

Berdasarkan Gambar 1.1. yang telah dipaparkan di depan, dapat dijelaskan lebih rinci sebagai berikut:

Tahap Identifikasi Rangsang: Pada tahap ini siswa atau atlet terjadi proses pengenalan rangsang yang datang. Faktor yang mempengaruhi tahap ini ialah faktor karakteristik rangsang, seperti kejelasan rangsang (jelas tidaknya informasi, baik verbal maupun visual).

Tahap Seleksi respons: Setelah seseorang mengenal rangsang yang datang, pada tahap selanjutnya adalah akan memilih suatu respons yang tepat. Misalnya pemain sepakbola yang sedang membawa bola dihadang oleh pemain lawan, maka ia harus memilih apa tindakan yang tepat. Apaka dia bearusaha melewati pemain yang sedang menghadang atau mengoperkan bola kepada temannya, hal itu membutuhkan proses memilih yang tepat dan cepat, jika tidak ia akan kehilangan momentum yang baik.

Tahap pemrograman respon: Setelah stimulus diidentifikasi dan respon diseleksi, selanjutnya diorganisasi untuk dijelmakan ke dalam motorik atau keterampilan. Dalam pembentukan rencana pelaksanaan ini, disamping ia memperoleh gambaran yang luas tentang tujuan dari keterampilan tersebut, siswa atau atlet harus memahami dari komponen-komponen gerakan. Kemudian apa yang dipelajari dalam fase pertama adalah rangkaian dari tugas tersebut. Biasanya demontrasi digunakan untuk membantu siswa memahami tujuan dan keterarmpilan maupun rangkaian organiasasi dari sub kebiasaan. Disamping mendemonstrasikan keterampilan, guru atau pelatih juga dapat menggunakan video atau film untuk membantu siswa agar dapat memahami keterampilan. Jadi guru atau pelatih dapat menggunakan audio visual dan persepsi 
dalam fase awal agar membantu siswa atau atlet menyempurnakan rencana pelaksanaannya dengan mekanisme reseptor (alat penerima) dan persepsi yang paling banyak digunakan dalam awal belajar keterampilan. Siswa dan atlet harus melihat gerakan, mendengar pengarahan verbal dan merasakan gerakan. Film dan video dapat menggambarkan suatu proses secara tepat yang dapat disaksikan secara berulang-ulang dalam waktu yang berbeda.

\section{Fase II: Tahap Latihan}

Setelah siswa atau atlet mengerti dan memiliki rencana pelaksanaan atau rencana motorik, ia harus mempraktekkan agar dapat memantapkan rangkaian penampilan atau keterampilan. Fitts mengistilahkan dengan "fase fiksasi" belajar keterampilan. Berapa jumlah praktek yang harus dilakukan untuk menguasai keterampilan tersebut akan bervariasi, sesuai dengan keunikan dari kegiatan, kemampuan dan pengalaman masa lampau dari individu yang bersangkutan. Dalam belajar fase kedua ini, siswa atau atlet harus mempraktekkan dengan baik dan sunguh-sungguh.

Kualitas keterampilan harus dikuasai pada fase dua ini. Tingkat keterampilan ditetapkan agar dicapai siswa atau atlet sendiri. Atlet akan menentukan berapa lama dan berapa kerasnya ia perlukan untuk berlatih.

\section{Fase III: Gerakan Otomatis}

Yang dimaksud dengan gerakan otomatisasi atau refleksi ialah gerakan yang dilakukan tanpa kesadaran atau perhatian (Rusli, 1988). Fase belajar keterampilan ini semakin ringan dalam menyelasaikan suatu tugas atau keterampilan, stress dan kecemasan yang dialami pelaku semakin menurun. Fitts (1965) menamakan fase ini fase otonom. Yang secara tidak langsung siswa atau atlet sekarang mampu melaksanakan suatu rencana atau program pelaksanaan dengan hampir tidak menyadarinya sama sekali. Pelaku telah melakukan gerakan tanpa melalui pemikiran yang panjang, bahkan tanpa tahu proses bagaimana suatu metode keterampilan dilakukan, termasuk keterampilan yang pada tahap awal dianggap sulit. Sekarang dapat melakukan seluruh pola gerakan secara otomatis dengan hasil yang cukup sempurna.

Bila pola gerakan telah mencapai tingkat otomatis,maka pelakutelahdapatberkomunikasi pada faktor lain yang tercakup dalam cabang olahraga tersebut. Pemain sepakbola yang menguasai teknik dasar maupun tembakan secara otomatis ia dapat berkonsentrasi untuk mengelak dari pemain lawan yang menghadangnya agar dapat mencapai posisi yang baik untuk melakukan tembakan. Pendek kata sebuah keterampilan yang dilakukan berulangulang (latihan) akan menghasilkan gerakan yang otomatisasi.

\section{Kajian Media Pembelajaran Audio Visual Un- tuk memperkuat Teori dan Konsep}

Belajar merupakan sebuah proses informasi, terdiri dari sebuah input-proses dan output. Menurut Bell-Gredler (2001) yaitu teori belajar yang memberi tekanan kepada pelacakan dan pemberian urutan pikiran manusia, tentang cara seseorang mempersepsi, mengorganisasi, dan mengingat sejumlah informasi yang diterima setiap hari dari lingkungannya, untuk dipakai dalam pemecahan masalah. Pemprosesan informasi terdiri atas tiga komponen yaitu: Penyimpanan informasi, proses kognitif dan metakognisi (Eggen dan Kauchak,1994). Alur pemprosesan informasi pertama kali dari lingkungan berupa benda-benda, cahaya, suara, bau dan sebagainya yang jumlahnya tidak terbatas diterima reseptor pada sistem syaraf. Dari reseptor, informasi ditandai oleh sensory register dalam bentuk yang terpola, setelah itu informasi ditahan dalam beberapa saat untuk dianalisa pendahuluan. Informasi yang dipilih untuk diolah dikirim ke dalam memori kerja (memori jangka pendek), dengan pengulangan terhadap informasi yang datang, menjadikan informasi tersebut menjadi bermakna sehingga akan diteruskan ke memori jangka panjang untuk disimpan secara tetap.

Informasi merupakan suatu masukan rangsangan dari luar, akan memberikan pengertian atau pengetahuan tentang sesuatu, yang disebut sebagai proses pembelajaran. Untuk penyampaian suatu informasi dapat dilakukan dengan berbagai metode, bisa dengan konsep (cognitif), secara visual dengan melihat langsung melalui pandangan mata, ataupun yang non visual seperti mendengarkan.

Dengan adanya perkembangan teknologi, informasi visual maupun non visual dapat disimulasikan dengan lebih nyata dan gampang ke dalam memori siswa dengan berbagai cara. Penggunaan berbagai macam media 
sangat dimungkinkan dengan adanya kemajuan teknologi tersebut, sehingga siswa akan lebih mudah menerima dan pemproses informasi menjadi suatu pengetahuan sehingga memperkuat konsep tentang sebuah keterampilan sepakbola.Semakin banyakalatinderayang dipergunakan untuk mempelajari pengetahuan, akan semakin mudah pengetahuan diserap. Untuk memperbanyak keterlibatan indera, salah satunya menggunakan media pembelajaran yang bervariasi. Media adalah segala sesuatu yang dapat digunakan untuk menyalurkan pesan dari pengirim ke penerima sehingga dapat merangsang pikiran, perasaan, perhatian dan minat serta perhatian siswa sedemikian rupa, sehingga proses belajar terjadi (Sadiman, 2005).

Manfaat penggunaannya media visual dalam pembelajaran sepakbola antara lain. 1. Media bersifat konkrit, lebih realistis dibandingkan dengan media verbal atau non visual sehingga lebih memudahkan dalam pengaplikasiannya. 2. Beberapa penelitian membuktikan bahwa pembelajaran yang diserap melalui media penglihatan (media visual), dapat mempercepat daya serap peserta didik dalam memahami pelajaran keterampilan.

Pengembangan siswa SSB dalam konteks penguasaan keterampilan ini diawali dengan pemahaman berbagai materi pelatihan terkait sepakbola usia dini (kognitif). Anak diajak memahami terlebih dahulu apa yang akan merekapraktekkan (psikomotor/keterampian). Setelah keterampilan artinya mereka berinteraksi dengan teman lain disitulah nilai-nilai keolahragaan muncul untuk diterapkan seperti sportif, fairplay (afektif). Pada dasarnya pemberian konsep dan audiovisual dilakukan sebagai alasan yang sangat masuk akal untuk memberikan gambaran konsep yang kuat pada kognitif anak tentang keterampilan yang akan dipraktekkan.

\section{Metode Pembelajaran dan Pelatihan}

Metode yang dikembangkan dalam pembelajaran di SSB menggunakan pembe-rian konsep dan audiovisual. Ada beberapa tahapan perkembangan kognitif dalam pembelajaran, yaitu:

\section{Tahap Perkembangan Kognitif Anak Me- nurut Piaget}

Perkembangan tahapan berpikir anak usia dini merujuk konsep yang dikembangkan oleh
Piaget. Pada tahapan usia dini untuk anak yang ikut program SSB berada pada operasional konkrit (usia 7-11 tahun) dan sampai juga mendekati cara berpikir formal; operasional. Pada dasarnya ada 4 tahapan yakni sensorimotor, pra operasional, operasional konkrit dan operasional formal. Terkait empat tahapan tersebut maka pada kajian ini difokuskan pada tahap operasional konkrit yang memang berada pada tahapan anak yang ikut program SSB. Tahap Operasional Konkret (usia 7 - 11 tahun), pada saat itu anak sudah belajar tentang aturan -aturan sederhana dalam kehidupannya. Pada tahapan ini seorang anak tidak hanya mampu mempraktikkan secara aktivits fisik, namun juga sudah bisa mereka lakukan secara kognisi. Ciri khas utama pada tataran ini adalah anak sudah mampu mengurutkan berbagai kategori. Misalnya membedakan ukuran bola yang bevariasi dari bola kecil sampai bola besar, dan berapa jumlah masing-masing bola. Memahami cara bermain, teknik bermain, taktik bermain dan aturan-aturan yang ada dalam permainan dari yang sederhana sampai yang kompleks.

Berdasarkan tahapan perkembangan kognitif anak, maka siswa SBB berada pada kemampuan yang sangat mendukung pemberian konsep-konsep dan didukung media audiovisual. Karena itu memahami suatu konsep dasar teknik bermain, aturan bermain, dan taktik bermain dalam permainan sepakbola untuk anak usia dini harus dilakukan. Persoalan berikutnya jika pemberian konsep dan audiovisual mampu diterima pada usia anak di SBB, maka bagaimana cara memberikan konsep tersebut. Maka tindak lanjutnya adalah menggunakan pendekatan taksonomi Bloom.

\section{Pengembangan Ranah Kognitif Pada Taksonomi Bloom}

Jika anak berada pada tahap operasional konkrit, maka anak diajak untuk mengetahui, memahami, sampai pada mampu menilai atau lebih tinggi lagi mampu mencipta. dari pemberian konsep tersebut yang didukung dengan audiovisual yang baik.

Kemampuan dasar mengurutkan dan menghubungkan sangat penting diketahui, agar konsep yang diberikan bisa tepat. Level terendah pada taksonomi Bloom dapat digunakan dengan memilihkata-kataoperasionalyang tepatsehingga mampu memberikan ciri khas pemberian konsep yang tepat dan mudah dipahami. 
Ada 3 ranah dalam taksonomi Bloom seperti dijelaskan berikut ini, yakni, a. Ranah kognitif yaitu mengingat, memahami, menerapkan, menganalisis, menilai, membuat, b.Ranah psikomotorik: meliputi, persepsi, kesiapan, reaksi yang diarahkan, reaksi natural (mekanisme), adaptasi, reaksi yang kompleks kreativitas, c. Ranah afektif: meliputi penerimaan, responsif, nilai yang dianut (nilai diri), organisasi dan karakterisasi.

Agar pemberian konsep dan media audiovisual lebih efektif, maka penggunaan kata-kata operasional yang tepat dapat digunakan dengan berbagai pertimbangan dan analisis yang tepat sesuai tahapan kognitif anak. Cukup banyak kata-kata operasional yang bisa digunakan dalam masa operasional konkrit yang sesuai dengan ranah kognitif anak. Pemilihan kata operasional akan menjadi ciri khas pemberian konsep dan audiovisual yang spesifik dan membedakan dengan metode pembelajaran lainnya.

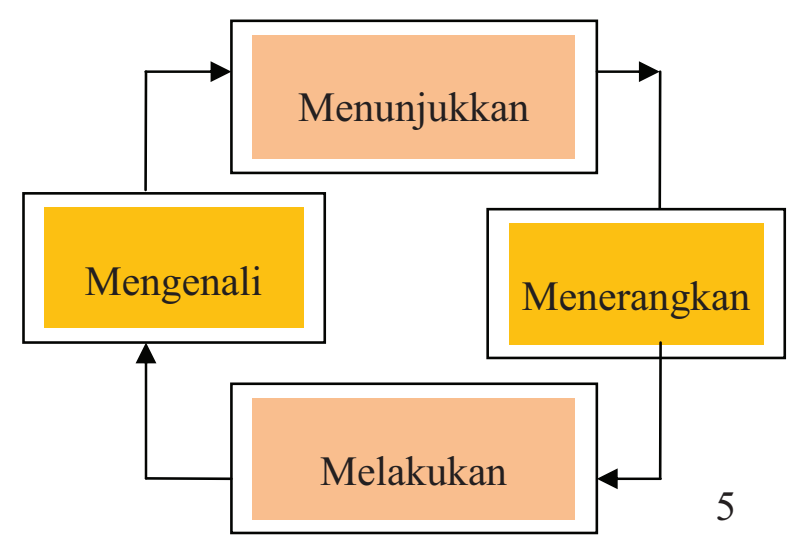

Gambar 1.2. Bagan Alur Pemberian Konsep pada Siswa SSB Sebelum Melakukan Keterampilan Sepakbola.

\section{a. Pemberian Konsep}

Pemberian konsep agar anak-anak SSB mudah memahaminya maka dapat digambarkan dalam siklus seperti ini. Berdasarkan bagan tersebut maka dalam materi SSB yang disampaikan oleh pelatih dengan memberikan konsep yang ada, maka diawali dengan level mengingat. Anak diajak mengenali terlebih dahulu konsep tersebut, kemudian apabila mereka sudah kenal lalu diminta untuk menunjukkan mana yang dikenali tersebut. Apabila sudah mampu menunjukkan maka dilanjutkan dengan menerangkan apa yang sudah dikenalnya. Tahap berikutnya adalah anak mampu melakukan dari konsep yang dikenali, ditunjukkan, kemudian diterangkan dan diakhiri praktik. Metode pemberian konsep ini dinamakan MENU-RAKU yakni mengenal, menunjukkan, menerangkan dan melakukan.

\section{b. Pemberian konsep dan media Audiovisual}

Seiring dengan perkembangan zaman, bahwa teknologi memberikan kontribusi dalam membantu proses pelatihan atau pembelajaran. Teknologi yang diperlukan adalah teknologi yang mudah dipahami oleh anak dan dalam suasana yang menyenangkan (joyful learning). Pemberian konsep dengan metode MENU-RAKU tidak akan maksimal tanpa adanya dukungan media audiovisual. Dengan bantuan media audiovisual anak akan mudah mengenali konsep yang dibicarakan dengan simbolisasi dengan bantuan media, dan mampu menunjukkan dengan bantuan media dan menerangkannya, setelah itu tanpa ada media audiovisual di sampingnya anak mampu melakukan dengan bahasa gerak tubuh yang tepat untuk mempraktikkan konsep-konsep yang sudah dikenali, ditunjukkan dan diterangkannya.

Berdasarkan paparan tersebut maka model MENU-RAKU dapat dikembangkan lagi dengan adanya penambahan media audivisual untuk pemberian konsepnya yakni:

1. Tahap mengenali, pelatih menyebut-an, menerangkan, memaparkan beberapa konsep dalam permainan sepakbola di SBB dibantu dengan teknologi berupa media audiovisual seperti tayangan video berbagai cara bermain termasuk dari pemain idola dan timidola, rekaman gerakan tertentu, dan video teknik serta taktik bermain. Anak diminta mengenali apa yang sudah dikenalkan oleh pelatih, sampai betul-betul kenal apa yang dipelajarinya.

2. Tahapmenunjukkan, pelatihmenunjukkan dengan penjelasan yang didukung dengan media audiovisual seperti menunjukkan tayangan video, analisis gerak dari contoh yang ada di tayangan video merujuk pada contoh-contoh terbaik. Anak diminta menunjukkan apa yang sudah dikenali tadi dengan 
122 | Adi Sucipto \& Budijanto, Pengembangan Model Kurikulum Sekolah Sepakbola (SSB) ...

tepat dan benar sesuai dengan apa yang dijelaskan oleh pelatih sebelumnya.

3. Tahap menerangkan, pelatih menerangkan apa yang sudah dikenalkan dan ditunjukkan pada anak dengan dukungan media audiovisual yang sudah dirancang sebelumnya. Anak diminta untuk menerangkan kembali dari apa yang sudah dikenali, ditunjukan dan diterangkan oleh pelatih dengan menggunakan bahasa anak sendiri bukan meniru kata atau kalimat yang dijelaskan oleh guru sebelumnya. Bantuan media audiovisual membuat keterampilan anak lebih baik, tidak hanya sebatas menerangkan tetapi mampu mempraktekkan seperti apa yang di media audiovisual.

4. Tahap melakukan, pelatih memberikan contoh praktik dengan gerakan tertentu baik teknik maupun fisik serta taktik, atau contoh aturan permainan dengan praktik langsung. Anak diminta ikut terlibat mampu mempraktikan dari apa yang sudah dikenali, ditunjukkan, diterangkan sebagai pondasi kognisi atau penguasaan konsep sebelumnya. Hal tersebut dilakukan berulang-ulang dengan materi yang baru dan berbeda. Sehingga suasana pelatihan untuk anak menjadi makin lebih menarik.Berdasarkan pemaparan metode MENURAKU maka tahap berikutnya adalah mengimplementasikan metode tersebut dengan cara mengujicobakan.

Dalam pemaparan silabus aktivitas kegiatan diambil kata-kata opersioanal tertinggi yaitu: melakukan, mempraktikkan, menerapkan, atau mengaplikasikan yang memiliki makna sama dengan melakukan dalam tahap terakhir di Metode MENU-RAKU. Artinya disilabus ditulis melakukan, tetapi pada praktiknya anak tidak langsung melakukan namun selalu diawali dengan mengenali, menunjukkan, menerangkan, dan kemudian melakukan dengan di dukung media udiovisual. Itulah ciri khas mendasar dalam pelatihan SSB dengan metode MENU-RAKU. Metode ini bisa dilihat dalam gambar 2.4. di bawah ini.

\section{Diagram Alir Pembelajaran}

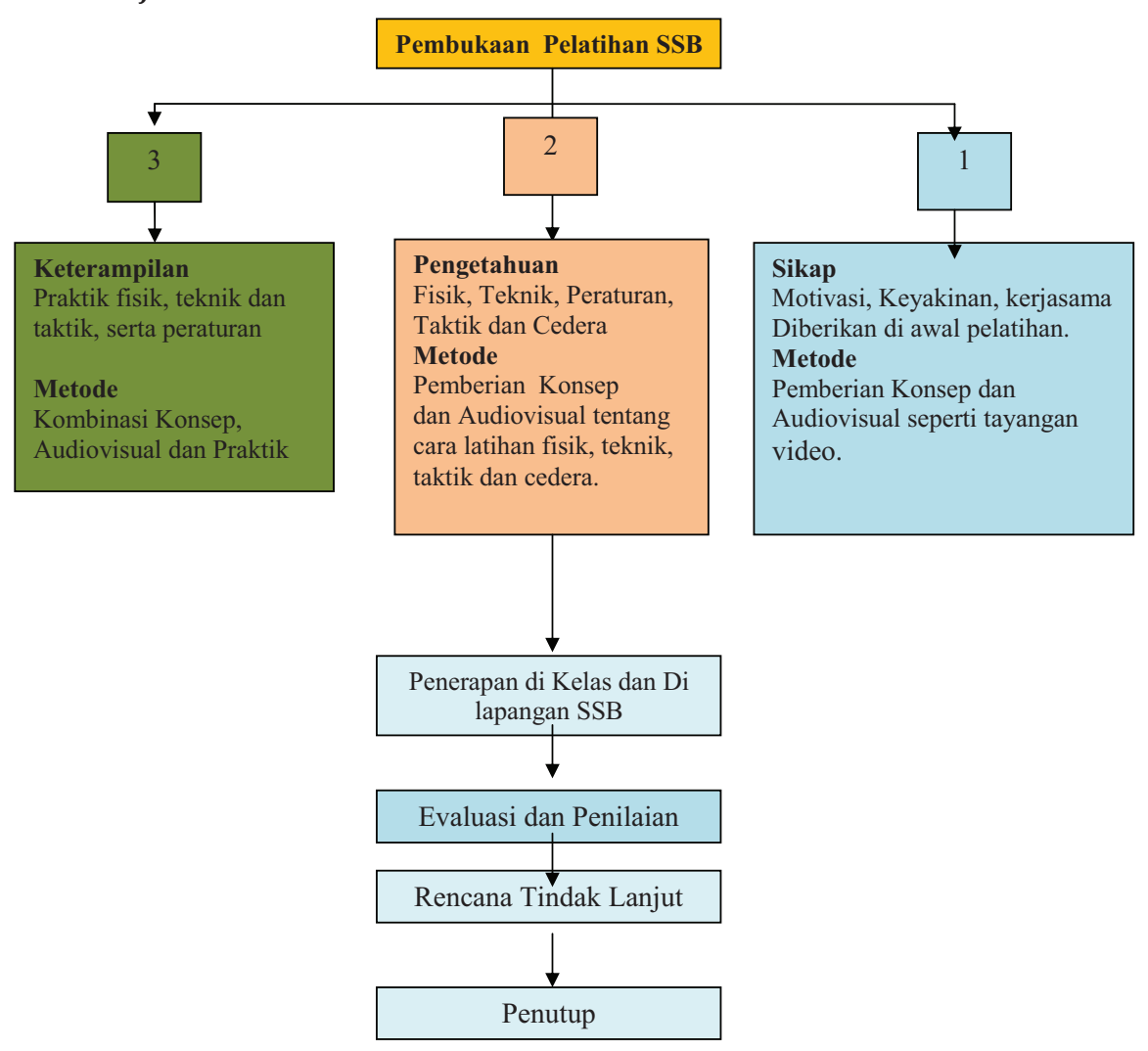

Gambar 1.3. Diagram Alur Pembelajaran Dan Pelatihan di SSB 


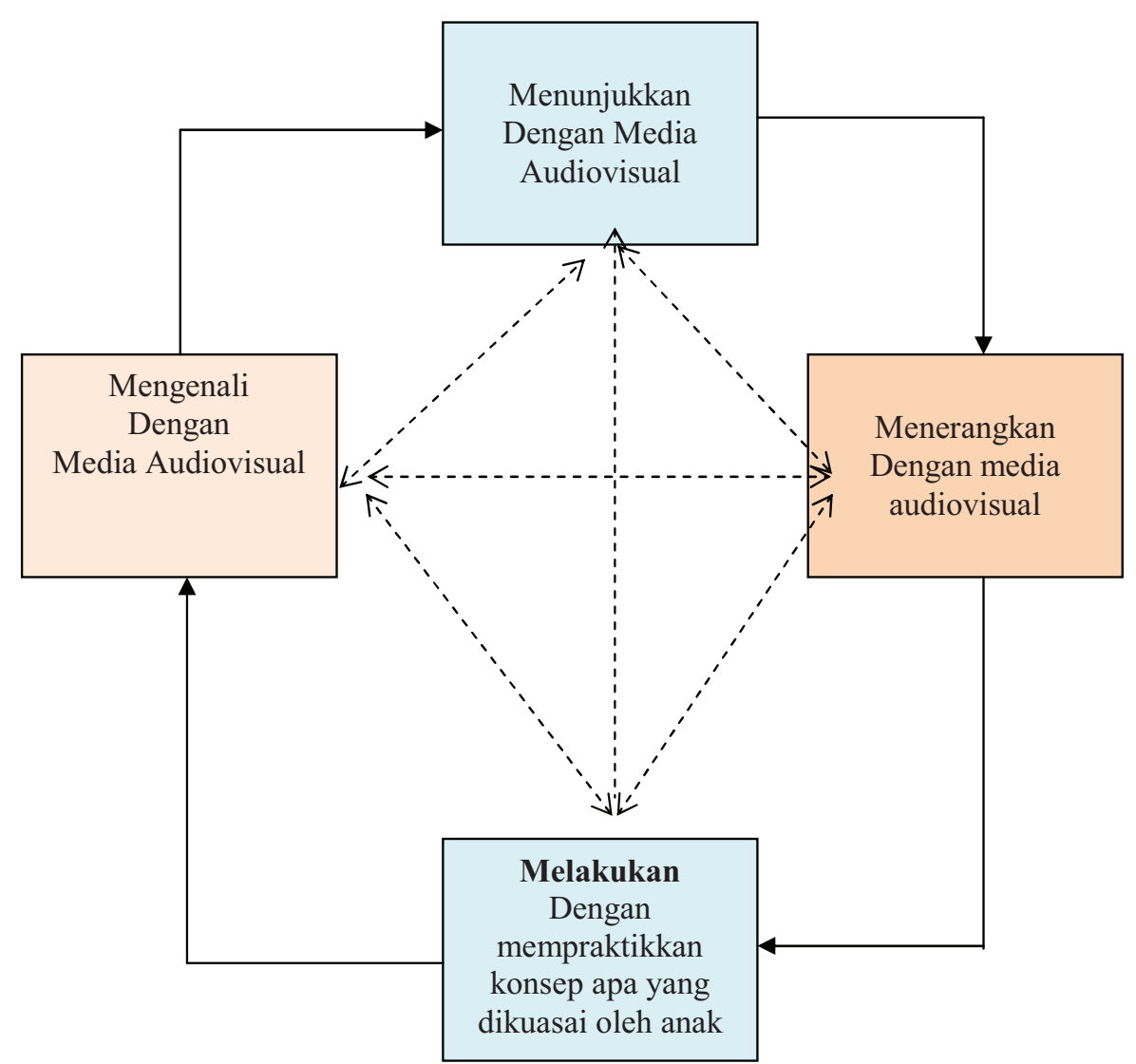

Gambar 1.4. Bagan alir pemberian media audio visual pada siswa SSB sebelum melakukan keterampilan sepakbola

\section{METODE}

Penelitian ini menggunakan rancangan penelitian deskriptif, danpengembangan. Pada tahap pertama ini menggunakan jenis rancangan penelitian deskriptif yang dilakukan dengan melalui: (1) Metode surview, bertujuan untuk memperoleh data kebutuhan akan model kurikulum pembelajaran di SSB. dan (2) Metode penelitian pengembangan yang bertujuan untuk menghasilkan produk berupa model kurikulum pembelajaran di SSB dengan pemberian konsep dan media audio visual. Model pengembangan yang dipakai ialah menggunakan pendekatan penelitian dan pengembangan (RED) model Borg and Gall (1983).

\section{HASIL DAN PEMBAHASAN}

Analisis kebutuhan kurikulum SSB dengan pemberian konsep dan audio visual dilakukan terhadap pelatih SSB yang ada di Kota Malang, Kabupaten Malang dan Kota Batu. Para pelatih menjawab pertanyaan yang berhubungan dengan perlunya suatu kurikulum SSB untuk meningkatkan keterampilan sepakbola. Dari berbagai pertanyaan yang diajukan kepada para responden, pengembangan kurikulum SSB dengan pemberian KONAV sebagain besar (87\%) menjawab perlu dikembangkan.

Berdasarkan evaluasi kelompok kecil ini, produk ini diujicobakan untuk memperoleh masukan konstruktif, agar nantinya dapat dilaksanakan dan diterima pada kancah sebenarnya. Tingkat keberadaan produk ini ditinjau dari tingkat urgensi, kebermanfaatan, kepraktisan, dan tingkat kesulitannya, serta perlu pelatihan sebelum menggunakan produk. Tingkat urgensidan kebermaknaan produk oleh $100 \%$ pelatih SSB sangat urgen dan bermanfaat. Hasil ini merupakan modal dasar yang paling penting untuk dikembangkannya produk, sebagai jawaban atas tingkat kebutuhan guru SSB yang tinggi terhadap kurikulum SSB.

Tingkat kepraktisan produk dinilai oleh $45 \%$ menyatakan sangat praktis, $25 \%$ menjawab praktisdan $30 \%$ menjawabtidakpraktis.Penilaian yang beragam ini penulis menduga disebabkan oleh keberagaman tingkat kompetensi pelaih SSB dalam menggunakan produk ini, dan keberadaan produk ini membutuhkan peralatan 
124 | Adi Sucipto \& Budijanto, Pengembangan Model Kurikulum Sekolah Sepakbola (SSB) ...

elektronik audio visual, sehingga para pelatih yang kurang terbiasa melakukannya dan masih diperlukan adaptasi dalam memahami dan menerapkan di lapangan.

Dari hasil analisis yang berkenaan dengan tingkat efisiensi dari segi waktu dan tenaga, dapat disimpulkan bahwa produk ini kurang efisien, artinya dalam menggunakanya diperlukan waktu dan tenaga dalam menyiapkan ruangan dan elektronik. Hasil evaluasi tentang kejelasan produk, dapat disimpulkan bahwa produk mempunyai tingkat kejelasan yang baik, sehingga lebih mudah dipahami. Uji coba produk ini dilakukan dengan jumlah ulangan yang lebih banyak, supaya validitas kurikulum hasilnya baik. Sehingga dapat disimpulkan bahwa pengembangan produk ini merupakan solusi yang tepat atas masalah yang dihadapi pelatih dalam memilih dan menggunakank kurikulum untuk meningkatkan keterampilan sepakbola. Ketidakpraktisan ini dengan alasan penggunaan persiapan sarana belajar membutuhkan waktu yang cukup lama, terutama mempersiapkan ruangan dan media audio visual. Mengenai tingkat efisiensi waktu $40 \%$ menjawab tidak efisien dan $60 \%$ efisien. Dengan demikian dari data ini dapat disimpulkan bahwa diperlukan waktu dan tenaga untuk mempersiapkan pelaksanaan pelatihan dengan pemberian konsep dan media audio visual ini.

Terkait biaya, penggunaan produk ini membutuhkan biaya yang relative cukup besar diawalnya akan tetapi selanjutnya lebih ringan. Keberagaman penilaian ini diduga disebabkan oleh keberagaman pengalaman, kompetensi situasi dan kondisi di lapangan. Sejalan dengan meningkatnya pengalaman dan kompetensi dalam menggunakan produk ini, diyakini akan mereduksi tingkat kesulitan yang muncul. Menyangkut masalah tingkat kejelasan produk untuk dipahami dapat disimpulkan bahwa produk ini mempunyai tingkat kejelasan yang baik karena semua pelatih SSB menilainya dengan pernyataan sangat jelas ataupun jelas, sehingga pengembangan kurikulum SSB dengan memberikan konsep dan audio visual bisa dilakukan dan dilanjutkan untuk meningkat keterampilan sepakbola.

\section{Pembahasan Hasil Desiminasi}

Hasil penelitian yang telah dilakukan menunjukkan bahwa keterampilan sepakbola siswa SSB dari 25 orang setelah mengikuti latihan sepakbola dengan pemberian KONAV mengalami peningkatan yang signifikan. Hal tersebut terbukti data rata-rata tes awal (pretest) passing 20.68, menggiring bola 32.80, dan menendang bola 25.20, sedangkan pada pengukuran akhir (posttest) diperoleh rata passing, 22.520, menggiring bola, 31.12, dan menendang bola 33.36. Hasil uji $t$ antara pretes dan postes diperoleh sebagai berikut: passing bola t-tes 9.325/ p.000, menggiring bola t-tes 8.159/ p.000 dan menendang bola 26.864/ p.000.

Hasil analisis statistik yang telah dipaparkan sebelumnya menunjukkan bahwa semua variabel penelitian mempunyai peningkatan keterampilan setelah mengikuti pelatihan sepakbola dengan pemberian KONAV.

\section{KESIMPULAN DAN SARAN}

Penelitian ini dimulai dengan analisis situasi, analisis masalah, analisis kebutuhan, rancangan pengembangan, validasi, uji coba terbatas dan revisi. Dari analisis situasi dan permasalahan ditemukan permasalahan yang sedang dialami siswa SSB baik yang disebabkan oleh faktor internal dan eksternal. Kebutuhan kurikulum sekolah sepakbola dengan pemberian konsep dan media audio visual, perlu diberikan kepada siswa SSB. Pemberian konsep sebelum latihan keterampilan bermanfaat menguatkan ingatan terkait keterampilan yang akan dilaksanakan. Materi pembelajaran yang diperoleh melalui media penglihatan (media visual), dapat mempercepat daya serap peserta didik dalam memahami pelajaran keterampilan.

Hasil Desiminasi: Hasil analisis statistik menunjukkan bahwa semua variabel penelitian mempunyai peningkatan keterampilan setelah mengikuti pelatihan sepakbbola dengan pemberian KONAV.

\section{DAFTAR RUJUKAN}

Bloom, B. New World Encyclopedia from http:/ / newworldencyclopedia.org/ entry/ Benjamin_diakses tanggal 13 Desember 2013.

Fitts, P.M. 1965. Perseptual Motor Skill Learning. In Aw. Melton (Ed) Academic Press, Inc New York.

Gagne, R. M. 1985. The Conditions of Learning. New York:Holt Renehart and Winston. 
h t t p : / / w w w . r i m a n e w s.com / $\mathrm{read} / 20110127 / 14252 /$ novel-barutentang-sepakbola-anak

Lutan, R. 2001, Pencarian Konsep dan Wilayah Batang Tubuh Ilmu Keolahragaan, Bandung, Pascasarjana UP.

Lutan, R. 1988. Berlajar Keterampilan Motorik. Depdikbud, Ditjen Dikti Jakarta.

Muhajir, 2011. Mata Pelajaran Pendidikan Jasmani, Olahraga dan Kesehatan di Sekolah Menengah Pertama (SMP/MTs) kelas VII.

Rahantoknam, B.E. 1988. Belajar Motorik, Teori dan Aplikasinya dalam Pendidikan Jasma- ni, Depdikbud, Ditjen Dikti Jakarta.

Reigeluth, C. 1992. Elaborating the elaboration theory. Educational Technology Research \& Development, 40(3), 80-86.

Sadiman, dkk. 1990. Media Pendidikan. Jakarta: Rajawali.

Scheunemann T., dkk. 2012. Kurikulum Sepakbola Indonesia Untuk Usia Dini (U5-U12), Usia Muda (U13-U20) \& Senior. Jakarta.

Schmidt, R.A. 1982. Motor Control and Learning, Chompaign: Human Kinetics Publisher, Inc.

Undang-undang No. 20 Tahun 2003 tentang Sistem Pendidikan Nasional. 